\title{
IMPLEMENTASI MEDIASI PADA PROSES PERCERAIAN TKI DI PENGADILAN AGAMA PONOROGO
}

Taufiqurohman
UIN Sunan Kalijaga Yogyakarta
e-mail: taufiqurohman09rildo@gmail.com
\begin{tabular}{|l|l|l|}
\hline Submit: 01-02-2021 & $\begin{array}{l}\text { Direvisi: 22-02-2021, } \\
\text { 26-03-2021 }\end{array}$ & Dipublish: 21-06-2021 \\
\hline
\end{tabular}

Abstract: This paper discusses the implementation of mediation in the Indonesian Worker (TKI) divorce process at Religious Court of Ponorogo. Recently, mediation has become an alternative in resolving cases outside the litigation path. The high number of divorce cases is increasingly concerning, for example in 2013, Religious Court of Ponorogo experienced an increase of 1,781 cases from 1,668 cases in 2012. After six years, the divorce rate is still quite high. Data for 2019 for the period of January-August, 422 cases of divorce, and 1,044 cases of divorce doubled. The cause of the divorce is mostly due to economic factors, the continuous bickering until these factors leave one party. Interestingly, cases of divorce include a married couple who work as migrant workers. Mediation as an important instrument in divorce prevention, as well as part of the court process, is the starting point for handling divorce for migrant workers. However, the existence of the parties because they work as migrant workers certainly has implications for the implementation of mediation. The approach used is a normative juridical approach, namely an approach based on the provisions of Islamic law and statutory regulations. As a result, TKI mediation in Religious Court of Ponorogo in 2013 reached 104 cases, all of which ended in failure. In addition, out of 104 cases, 81 cases were decided one after another because one party never attended and was abroad.

Kata kunci: Perkawinan, Mediasi, Perceraian, TKI.

\section{PENDAHULUAN}

Kehidupan berumah tangga ibarat roda yang berputar, adakalanya kehidupan rumah tangga begitu harmonis dan bahagia namun juga kadang mengalami fase ketidakcocokan pasangan suami istri. Konflik dan persoalan yang terjadi bisa disebabkan oleh berbagai sebab dan alasan seperti prinsip, watak, dan lain sebagainya. Apabila perselisihan dan konflik ini tidak dikelola secara baik, berkecendrungan terjadinya percekcokan, tidak jarang memuncak sampai terjadinya perceraian. (AF, 1987: 165)

Kasus perceraian yang terjadi secara kuantitatif semakin hari semakin naik, menurut data yang penulis dapatkan dari laman resmi Badan Peradilan Agama Mahkamah Agung, menunjukkan bahwa perceraian di Ponorogo pada tahun 2019 terjadi 2.069 kasus (Badilag Mahkamah Agung). Senada dengan hal tersebut, Ketua Pengadilan Agama Ponorogo Asrofi dalam kesempatan tersebut memaparkan kasus perceraian di Ponorogo tahun 2019 didominasi oleh cerai gugat oleh pihak istri daripada cerai talak dari pihak suami (rri.co.id, 19 Februari 2020). Kurang lebih 21\% (451 kasus) di antaranya adalah kasus perkara perceraian Tenaga Kerja Indonesia (TKI). TKI atau biasa dikenal dengan buruh migran adalah tenaga orang Indonesia yang bekerja di luar negeri. Kabupaten Ponorogo merupakan salah satu wilayah yang cukup tinggi yang mengirim TKI di 
luar. Kebanyakan dari buruh migran ini bekerja di wilayah Asia Timur seperti di Korea, Hongkong dan Taiwan. Selain itu rata-rata dari Tenaga Kerja Wanita (TKW) tersebut telah memiliki keluarga (telah menikah) yang ditinggalkan di kampung halaman. (Muawwanah, 2019: 155)

Guna mempermudah pembaca dalam mengikuti alur analisis pada paper ini, penulis sampaikan bahwa penelitian ini dilakukan pada tahun 2014 dengan menelaah, mengkaji, mengolah dan mengelompokkan berkas perkara perceraian dengan latar belakang TKI pada tahun 2013 di Pengadilan Agama Ponorogo, dengan menggunakan pisau analisis utama PERMA No 1 Tahun 2008. Sehubungan dengan lahirnya revisi menjadi PERMA No 1 Tahun 2016, penulis melihat kontekstualisasi penelitian ini masih relevan dengan keadaan saat ini jika melihat dan mempertimbangkan angka perceraian TKI dan buruh migran yang berasal dari Ponorogo setiap tahun menunjukkan peningkatan.

Berdasarkan pada data Penempatan dan Perlindungan PMI-BP2MI (Badan Perlindungan Pekerja Migran Indonesia), Ponorogo menempati posisi keempat di Indonesia Penempatan Pekerja Migran Indonesia dengan 10.043 pekerja tahun 2018 dan 9.665 pekerja tahun 2019. Sedangkan pada periode 2014-2018, ponorogo menempati posisi keenam Penempatan Pekerja Migran Indonesia. (www.bnp2tki.go.id)

Usaha-usaha penanggulangan perselisihan rumah tangga khususnya perceraian pasangan TKI banyak cara dan sarana yang bisa ditempuh guna mempertahankan keutuhan rumah tangganya. Ada yang menyelesaikan secara pribadi dan ada juga melalui pihak ketiga seperti ulama atau modin (tokoh masyarakat). Pengadilan Agama berdasarkan keluarnya PERMA No. 1 Tahun 2016, menjadikan mediasi sebagai alur yang wajib dilalui manakala perkara telah masuk di pengadilan tidak terkecuali perceraian, jika perkara yang masuk tersebut tidak menempuh prosedur mediasi maka berakibat putusan batal demi hukum.

Mediasi adalah upaya dalam mendamaikan dan menengahi perkara secara kekeluargaan (win win solution) melalui pihak ketiga yang disebut sebagai mediator. Mediasi di sebagian literatur juga disebut sebagai family counseling, karena upaya bantuan ini adalah bentuk dari pekerjaan sosial level mezzo yang dilakukan oleh tenaga profesional yang telah terlatih yakni mediator (Fadili, 2019: 19). Sebagimana yang telah diatur dalam Peraturan Mahkamah Agung No. 1 tahun 2016 bahwa mediasi merupakan bagian dari amanah undang-undang untuk dilaksanakan, sehingga proses beracara di pengadilan bisa sesuai dengan asasnya, yakni cepat, sederhana dan biaya murah. (Sunarto, 2019: 98)

Mahkamah Agung telah 'merubah' paradigma mengadili menjadi paradigma menyelesaikan perkara hukum. Penyelesaian sengketa perkara perdata melalui litigasi mulai ditinggalkan dan beralih ke Alternative Dispute Resolution/ADR (Alternatif Penyelesian Sengketa/APS) (Saragih \& Simanjuntak, 2020: 735). Dengan kata lain, hadirnya mediasi di pengadilan adalah salah satu langkah yang ditempuh untuk menyelesaikan perkara-perkara yang masuk. 
Melihat historitas mediasi, secara kontekstual penyelesaian sengketa melalui metode mediasi atau mendamaikan telah lama dikenal dalam hukum Islam. Hanya saja pada waktu itu bukan bernama mediasi melainkan tahkim (Rosadi, 2018: 107). Pasal 4 ayat (1) PERMA No. 1 Tahun 2016 menjelaskan dan menetapkan bahwa semua sengketa perdata yang diajukan ke pengadilan wajib terlebih dahulu diupayakan penyelesaian melalui mediasi. Mediasi dalam sengketa perkawinan khususnya pada perkara perceraian memberikan manfaat yang besar bagi para pihak yang bersengketa, karena melalui mediasi maka akan dicapai kesepakatan dan solusi yang dapat menjadi 'wasilah' terselesaikannya masalah yang menjadi penyebab keretakan rumah tangga sehingga keutuhannya tetap terjaga.

Proses mediasi bagi pasangan TKI yang dimaksud penulis adalah proses mediasi bagi pasangan suami istri di mana suami, istri atau kedua-duanya berkerja di luar negeri seperti Hongkong, Taiwan, Malaysia, Singapura, dan Brunei Darussalam yang hendak bercerai di Pengadilan Agama Ponorogo. Proses mediasi yang dilakukan, apabila berhasil mencapai kemufakatan damai kemudian mediator membuat akta perdamaian yang dicetak dan diterbitkan berdasarkan kesepakatan kedua belah pihak. Jika mediasi dinyatakan gagal oleh mediator, maka hakim akan melanjutkan pemeriksaan perkara.

Sangat menarik mengkaji proses mediasi terhadap pasangan TKI. Selain menjadi salah satu bagian dari kasus perceraian di Pengadilan Agama Ponorogo, juga bagaimana mekanisme mediasi jika terjadi kemungkinan- kemungkinan apabila salah satu pihak masih berada di luar negeri, tentunya ini mempunyai akibat hukum yang berdampak terhadap perceraian mereka. Sejalannya ketentuan agama maupun hukum ini membuat penulis tertarik mengadakan penelitian persoalan ini dan menuangkannya dalam tulisan ini.

\section{METODE PENELITIAN}

Penelitian ini merupakan penelitian pustaka dengan menelaah berkas perkara, jurnal terkait topik pembahasan, atau dokumen terkait dengan perceraian dan mediasi TKI yang bersumber dari Pengadilan Agama Ponorogo. Sumber tertulis di antaranya 104 bandel perkara perceraian TKI tahun 2013 serta data dari buku Register Gugatan Panitera Muda Hukum. Sifat penelitian ini adalah deskriptif analisis. Sedangkan pendekatan yang digunakan adalah normatif-yuridis, yaitu pendekatan yang berpijak pada ketentuan hukum Islam serta pendekatan berdasarkan perundang-undangan atau peraturan yang mengatur prosedur kerja dalam bermediasi.

Adapun metode pengumpulan data adalah melalui dokumentasi dan interview. Dokumentasi digunakan untuk melacak sejumlah data baik berupa bukubuku, surat-surat, laporan atau yang lainnya yang berada di Pengadilan Agama Ponorogo terkait perceraian TKI dan pelaksananaan mediasi. Sedangkan metode interview yang digunakan pada penelitian ini adalah interview bebas terpimpin. Interview dilakukan langsung dengan Hakim Mediator dan Panitera Muda Hukum di Pengadilan Agama Ponorogo, wawancara ini dilakukan untuk memperjelas data yang diperoleh 
melalui data tertulis. Penulis kemudian menganalisa data dalam penelitian ini dengan metode kualitatif. Analisis tentang perkara perceraian pasangan TKI di Pengadilan Agama Ponorogo, kemudian ditarik kesimpulan metode penerapan dan efektifitas dalam proses mediasi bagi pasangan TKI ini.

\section{PERCERAIAN TKI DAN HAL-HAL YANG MEMPENGARUHINYA}

Meningkatnya pekerja imigran dari Kabupaten Ponorogo menjadi poin utama bagi pemerintah setempat, seperti sumber data yang dirilis BPS Kabupaten Ponorogo, menunjukkan bahwa jumlah TKI laki-laki pada tahun 2016 sebanyak 1240 dan wanita sebanyak 3.662 orang, sehingga total TKI tahun 2016 sebanyak 4902. Jumlah tersebut mengalami peningkatan 179 orang pada tahun 2016 jika dibandingkan tahun 2015 (4723 orang) (Statistik, 2016: 67), nyatanya tidak selalu berdampak positif bagi keluarganya. Namun juga menimbulkan dampak negatif, seperti munculnya problemproblem pernikahan yang tidak jarang berujung pada gugatan bahkan perceraian. Situasi dan kondisi menjelang perceraian yang diawali dengan proses negosiasi antara pasangan suami istri berakibat pasangan tersebut sudah tidak menghasilkan kesepakatan yang dapat memuaskan masing-masing pihak (Nasution, 2019: 5).

Hasil yang penulis dapatkan dari mengidentifikasi jumlah kasus perceraian TKI pada tahun 2013 di Pengadilan Ponorogo sebagaimana tabel di bawah ini:

Tabel 3

Perkara Perceraian di Pengadilan Agama Ponorogo

\begin{tabular}{|c|c|c|c|}
\hline \multirow{2}{*}{ No. } & \multirow{2}{*}{ Bulan } & \multicolumn{2}{|c|}{ Perceraian } \\
\cline { 3 - 4 } & & Cerai Talak & Gugat Gerai \\
\hline 1 & Januari & 58 & 117 \\
\hline 2 & Februari & 59 & 107 \\
\hline 3 & Maret & 46 & 91 \\
\hline 4 & April & 58 & 121 \\
\hline 5 & Mei & 61 & 112 \\
\hline 6 & Juni & 51 & 101 \\
\hline 7 & Juli & 49 & 88 \\
\hline 8 & Agustus & 31 & 51 \\
\hline 9 & September & 43 & 80 \\
\hline 10 & Oktober & 69 & 147 \\
\hline 11 & Nopember & 47 & 108 \\
\hline 12 & Desember & 49 & 93 \\
\hline & & $\mathbf{6 2 1}$ & $\mathbf{1 2 1 6}$ \\
\cline { 3 - 4 } & & \multicolumn{2}{|c|}{} \\
\hline
\end{tabular}

Sumber: Diolah dari berkas perkara di ruang arsip tahun 2013 Perkara Perceraian Pengadilan Agama Ponorogo 
Tabel 4

Jumlah Perceraian TKI

\begin{tabular}{|c|l|c|}
\hline No. & \multicolumn{1}{|c|}{ Bulan } & Perceraian TKI \\
\hline 1 & Januari & 1 \\
\hline 2 & Februari & 7 \\
\hline 3 & Maret & 8 \\
\hline 4 & April & 16 \\
\hline 5 & Mei & 11 \\
\hline 6 & Juni & 10 \\
\hline 7 & Juli & 3 \\
\hline 8 & Agustus & 1 \\
\hline 9 & September & 8 \\
\hline 10 & Oktober & 9 \\
\hline 11 & November & 12 \\
\hline 12 & Desember & 18 \\
\hline \multicolumn{2}{|c|}{ Jumlah } & $\mathbf{1 0 4}$ \\
\hline
\end{tabular}

Sumber: Diolah dari berkas perkara di ruang arsip tahun 2013 Perkara Perceraian Pengadilan Agama Ponorogo

Tabel 5

Jumlah Perceraian TKI

\begin{tabular}{|c|l|c|}
\hline No. & Jenis Perkara Perceraian TKI & Jumlah \\
\hline 1 & Cerai Gugat & 100 \\
\hline 2 & Cerai Talak & 4 \\
\hline \multicolumn{2}{|c|}{ Jumlah } & $\mathbf{1 0 4}$ \\
\hline
\end{tabular}

Sumber: Diolah dari berkas perkara di ruang arsip tahun 2013 Perkara Perceraian Pengadilan Agama Ponorogo

Jumlah perceraian TKI pada tahun 2013 menunjukkan 104 pasang perkara. Pasangan TKI yang dimaksud adalah salah satu di antaranya bekerja di luar negeri, baik suaminya maupun istrinya yang menjadi tulang punggung nafkah keluarga. Menariknya, data menunjukkan bahwa 104 perkara perceraian pasangan TKI 81 diputus dengan putusan verstek (tidak dihadiri salah satu pihak) karena masih di luar negeri yang artinya tidak melewati proses mediasi.

Ketidakhadiran tergugat/termohon secara ekplisit sudah menegaskan keinginannya dan persetujuannya untuk tetap melanjutkan perceraian. Keadaan demikianlah yang juga menutup kesempatan mediasi, dan hakim mediator sesuai dengan tugas pokok dan fungsinya tidak mampu mengupayakan mediasi secara imperatif. Kehadiran para pihak dalam proses mediasi sangat menentukan keberhasilan mediasi. Jika mediasi hanya dihadiri oleh satu pihak maka otomatis mediasi tidak bisa dilaksanakan dan dianggap gagal proses selanjutnya adalah sidang pemeriksaan perkara di depan para yang mulia. (Handayani \& Syafliwar, 
2017: 248). Sistemasi demikianlah yang menutup upaya-upaya penyelesaian perkara berkelanjutan melalui jalur litigasi.

Menyelesaikan konflik dengan mediasi berarti menyelesaikan konflik dengan negosiasi, (Wirawan \& Konflik, 2009: 200) negosiasi disini berarti suatu proses sementara di mana para pihak saling tawar menawar (bargaining) secara sukarela guna mencapai suatu kesepakatan atau solusi.

Solusi yang didapat dari objek konflik ini ditentukan oleh pihak-pihak yang terlibat konflik itu sendiri. Jika kerelaan menghadiri acara di pengadilan tidak tunaikan maka proses mediasi secara jelas dikatakan telah tertutup dan kecil kemungkinan bisa ruju' dan Kembali menjaln hubungan rumah tangga yag ideal.

Perceraian bagi pasangan TKI meskipun secara angka tidak dominan dibanding dengan perceraian status masyarakat umumnya, namun perceraian TKI memiliki pengaruh di tengah-tengah masyartakat. Berikut pengaruhnya:

\section{Sosial}

Pasangan suami istri yang salah satunya bekerja di luar negeri secara umum bekerja dalam durasi kontrak kerja yang cukup lama yaitu antara 2-3 tahun. Mengingat lamanya berpisah dengan keluarga di rumah ini, jika terjadi perceraian maka masyarakat memandang bahwa bekerja di luar negeri adalah penyebab keretakan rumah tangga yang utama.

\section{Ekonomi}

Bekerja di luar negeri adalah pekerjaan yang cukup menjanjikan untuk membantu perekonomian keluarga. Jika perceraian TKI ini semakin meningkat maka minat masyarakat bekerja di luar negeri akan berkurang dan terbukanya peluang pengangguran di Kabutapen Ponorogo secara khusus, dan daerahdaerah lainnya secara umum.

Memperhatikan dampak yang dapat terjadi secara sosial dan ekonomi di atas, bagaimana dan seperti apa penerapan mediasi pada pasangan TKI sangat berperan penting guna menutup pintu perceraian TKI di jalur litigasi. Mediator diartikan bukan hanya memberi pelayanan saja (mendamaikan pihak yang berselisih), namun juga dituntut tanggap atas berbagai permasalahan yang sedang dihadapi pihak yang mengalami perselisihan rumah tangga.

Tanggap dan cakap atas berbagai permasalahan yang dihadapi pasangan TKI menjadi salah satu faktor pendukung dalam keberhasilan memediasi. Namun, tampaknya belum semua mediator mengaplikasikan metode ini, sehingga mediasi hanya sebagai formalitas (Usman, 2012: 27) yang dilakukan manakala perkara diajukan ke pengadilan. Jika kondisi ini dibiarkan dan tidak ada evaluasi, maka mediasi akan berujung dengan kegagalan.

Kembali pada ketentuan Pedoman Perilaku Mediator Pasal 8 tentang Kemampuan/Ketrampilan menjelaskan bahwa: "Mediator diharapkan untuk senantiasa meningkatkan kemampuan atau ketrampilan tentang mediasi melalui pendidikan, pelatihan, seminar dan konferensi."

Pedoman perilaku mediator ini menunjukkan bahwa dalam memediasi, mediator dituntut untuk memahami serta mengerti permasalahan yang dihadapi para pihak yang berkonflik (Mustofa, 2017). Sebab, tingkat kebutuhan para 
pihak yang terlibat konflik terhadap intervensi mediator tidaklah sama. Dengan menimbang besar-kecilnya intervensi mediator ini, maka mediator dapat melakukan pemetaan konflik guna mengumpulkan hasil kesepakatan kedua belah pihak. Hal yang perlu dipetakan di antaranya identifikasi pihak-pihak yang terlibat konflik dan analisis penyebab konflik. (Wirawan \& Konflik, 2009: 209)

Selanjutnya, guna mengatasi permasalahan para pihak yang tidak dapat hadir karena masih berada di luar negeri, hemat penulis Pengadilan Agama sudah saatnya untuk melaksanakan PERMA No. 1 Tahun 2016 Pasal 5 ayat (3) tentang penggunaan alat komunikasi bagi pihak yang tidak dapat bertatap muka dalam satu majlis.

\section{IMPLEMENTASI MEDIASI PADA PERCERAIAN TKI}

Berangkat dari hasil penelitian perceraian TKI di Pengadilan Agama Ponorogo Tahun 2013, didapatkan bahwa memediasi, menengahi dan mencari titik temu pada pasangan TKI tetap disamakan dalam mediasi perceraian lainnya. Walaupun PERMA tidak mengatur secara khusus mediasi berdasarkan jenis dan latar belakang para pihak yang berperkara, namun mediator hendaknya membedakan penanganan setiap perceraian terlebih pasangan TKI. Pedoman Perilaku Mediator Pasal 4 menyebutkan: "Mediator wajib menyelenggarakan proses mediasi sesuai dengan prinsip penentuan diri sendiri oleh para pihak."

Pedoman ini menunjukkan bahwa dalam memediasi, mediator hendaknya menyesuaikan terhadap para pihak sesuai kondisi dan situasi pihak yang dimediasi.

Tabel 6

Hasil Mediasi Perceraian TKI

\begin{tabular}{|c|c|c|c|c|c|c|}
\hline \multirow{2}{*}{ No. } & \multirow{2}{*}{ Bulan } & \multicolumn{4}{|c|}{ Putusan } & \multirow{2}{*}{$\begin{array}{c}\text { Hasil } \\
\text { nediasi }\end{array}$} \\
\cline { 3 - 6 } & & Verstek & Gugur & Nihil & Mediasi & - \\
\hline 1 & Januari & 1 & 0 & 0 & 0 & Gagal \\
\hline 2 & Februari & 5 & 0 & 1 & 1 & Gagal \\
\hline 3 & Maret & 5 & 0 & 0 & 3 & Gagal \\
\hline 4 & April & 10 & 0 & 2 & 4 & Gagal \\
\hline 5 & Mei & 8 & 1 & 1 & 1 & Gagal \\
\hline 6 & Juni & 7 & 1 & 0 & 2 & - \\
\hline 7 & Juli & 2 & 0 & 0 & 1 & Gagal \\
\hline 8 & Agustus & 1 & 0 & 0 & 0 & - \\
\hline 9 & September & 8 & 0 & 0 & 0 & Gagal \\
\hline 10 & Oktober & 7 & 0 & 1 & 1 & Gagal \\
\hline 11 & November & 11 & 0 & 0 & 1 & - \\
\hline 12 & Desember & 16 & 0 & 2 & 0 & \\
\hline \multicolumn{2}{|c|}{ Jumlah } & $\mathbf{8 1}$ & $\mathbf{2}$ & $\mathbf{7}$ & $\mathbf{1 4}$ & \\
\hline
\end{tabular}

Sumber: Diolah dari berkas perkara di ruang arsip tahun 2013 Perkara Perceraian Pengadilan Agama Ponorogo 
Memediasi pasangan TKI yang sedang berkonflik memerlukan metode yang berbeda. Penanganan dan mediasi yang khusus ini mempertimbangkan bahwa mediasi TKI salah satu pihak berada di luar negeri. Memang pola mediasi yang dilakukan mediator mempunyai pola yang sama dengan perkara lain, namun proses mediasi persengketaan perkawinan berbeda-beda dilihat dari intensitas konflik yang terjadi dan keadaan para pihak yang berkonflik.

Perceraian pasangan TKI pada tahun 2013 sebanyak 104 perkara, terdiri dari 100 perkara cerai gugat dan 4 perkara cerai talak. Data yang penyusun dapatkan bahwa $100 \%$ cerai gugat ini dilakukan oleh pihak istri, yang berprofesi sebagai TKI di luar negeri. Tingginya cerai gugat ini tidak bisa dilepaskan dari peran dan tanggung jawab laki-laki sebagai suami selama ditinggal di luar negeri sebagai TKI.

Banyaknya putusan verstek pada perceraian TKI, disebabkan karena salah satu pihak tidak pernah hadir dalam pemanggilan atau masih berada di luar negeri karena kontrak kerja. Jika dalam keadaan demikian maka mediasi tidak dapat dilaksanakan dan dilanjutkan dengan pemeriksaan perkara. Hal ini dilakukan karena Majelis Hakim melihat kondisi rumah tangga yang sudah tidak memungkinkan lagi untuk didamaikan, seperti pihak Tergugat telah melakukan perselingkuhan atau pergi meninggalkan rumah bersama tanpa kejelasan kabar dan tanggungjawab kepada keluarganya dalam waktu yang cukup lama.

PERMA No. 1 Tahun 2016 pada dasarnya telah mengatur kemungkinan pelaksanaan mediasi dengan bantuan alat komunikasi seperti internet jika salah satu pihak tidak memungkinkan bertatap muka. Ketentuan ini termuat pada Pasal Pasal 13 ayat (6) : "Jika diperlukan dan atas dasar kesepakatan para pihak, mediasi di pengadilan dilakukan secara jarak jauh dengan menggunakan alat komunikasi". Atau dalam pembaharuan PERMA 2016 pada Pasal 5 ayat (3) disebutkan: "Pertemuan Mediasi dapat dilakukan melalui media komunikasi audio visual jarak jauh yang memungkinkan semua pihak saling melihat dan mendengar secara langsung serta berpartisipasi dalam pertemuan". Namun hal ini menurut Drs. Abdullah Shofwandi (Hakim Mediator) belum pernah diaplikasikan dalam proses mediasi, walaupun tingkat perceraian TKI cukup tinggi dibanding Pengadilan Agama lain (mengambil perbandingan dengan Pengadilan Agama Situbondo)

Proses mediasi dilakukan secara tertutup diruangan yang telah disediakan oleh pengadilan. Mediasi pada pasangan TKI yang salah satu pihak berada di luar negeri dan menguasakan kepada kuasa hukum, sangat berpengaruh terhadap hasil mediasi. Pemberian kuasa istimewa ini hanya sebatas beracara dengan kata lain pihak yang dibela hadir hanya untuk bercerai, sehingga mediator tidak dapat menyampaikan hal-hal yang mendasar terkait penasihatan dan pengambilan keputusan.

Sebagaimana dalam prosedur dan alur mediasi yang dijelaskan dalam PERMA bahwa pada sesi pertemuan pertama mediator menjelaskan secara singkat proses mediasi kepada para pihak. Kendala yang paling besar terhadap mediasi pasangan TKI yang akan bercerai 
selain salah satu pihak berada di luar negeri adalah mereka datang ke pengadilan karena niat untuk bercerai sudah final dan kuat. Sehingga proses mediasi berlangsung alot dan berakhir dengan kegagalan.

Mediasi yang dinyatakan gagal, selanjutnya dilanjutkan pada proses pemeriksaan perkara. 2 (dua) perkara yang gugur dari 104 perkara perceraian pasangan TKI pada tahun 2013, 1 (satu) di antaranya adalah masuk katagori akibat dari mediasi yang berhasil. Artinya walaupun putusan gugur ini terjadi di tengah pemeriksaaan perkara karena salah satu pihak mencabut gugatannya, menurut Hakim Mediator Drs. Abdullah Shofwandi hal ini sebagai keberhasilan perdamaian yang 'tidak langsung' dari proses mediasi. Sedangkan satu perkara yang gugur karena pihak Penggugat tidak hadir dalam persidangan setelah dipanggil dua kali berturut-turut.

Melihat kondisi seperti ini Pengadilan Agama Ponorogo belum mempunyai cara ataupun metode khusus dalam memediasi perceraian pasangan TKI, hal ini disebabkan kendala teknis seperti belum adanya alat komunikasi berupa teknologi penunjang teleconfrence, ataupun non teknis seperti tidak sebandingnya jumlah mediator dengan skala perkara yang masuk di pengadilan.

Menurut Ramdan Jaelanai-Panitera Muda Hukum di Pengadilan Agama Ponorogo, bahwa hasil mediasi yang hampir $100 \%$ gagal pada pasangan TKI yang akan bercerai. Pengadilan Agama sudah sering membahas dalam rapat pertemuan, namun secara khusus belum ada evaluasi bulanan atau tahunan untuk mengatasi hal tersebut. Walaupun secara angka perceraian pasangan TKI tidak terlalu mencolok, namun Pengadilan Agama Ponorogo pernah diundang oleh komisi III DPRD Ponorogo untuk mengklarifikasi laporan masyarakat tentang perceraian pasangan TKI. Terlepas apakah perceraian TKI sebagai pemicu utama di Pengadilan Agama ponorogo ataupun tidak, hal ini tetap mendapat perhatian khusus bagi Pengadilan Agama Ponorogo.

Penulis menyimpulkan bahwa mediasi pada pasangan TKI ini perlu diberikan ruang khusus dalam proses maupun penyelesaiannya di Pengadilan, dengan pertimbangan sebagai berikut:

1. Data menunjukkan bahwa 104 perkara perceraian pasangan TKI 81 diputus dengan putusan verstek, yang artinya tidak melewati proses mediasi.

2. 14 perkara peceraian pasangan TKI tahun 2013 yang dimediasi semuanya gagal;

3. Sesuai data statistik BNP2TKI Kabupaten Ponorogo berada diurutan ke-11 dengan jumlah 10.494 TKI penempatan ke luar negeri, dengan demikian banyak sekali penduduk yang berlatar belakang TKI dan terbukanya peningkatan angka perceraian.

Islam juga sejalan dengan adanya mediasi dalam menyelesaiakan dua orang yang sedang berkonflik. Mediasi atau perdamaian atau islah dalam Islam merupakan tindakan yang bermaksud menyelesaikan dua orang atau lebih yang berperkara sesuai kehendak para pihak. Suami istri yang sedang berselisih (syiqaq), Allah SWT. menjelaskan dalam Al-Qur'an untuk mengutus hakam atau juru damai. Pengutusan hakam mempunyai maksud sebagai pencari jalan keluar terhadap 
kemelut rumah tangga. Ketentuan ini termuat dalam firman Allah SWT. berikut:

$$
\begin{aligned}
& \text { وإن خفتم شقاق بينهما فابعثوا حكما من أهله و }
\end{aligned}
$$

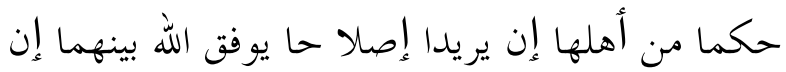

$$
\begin{aligned}
& \text { الله عليما خبيرا }
\end{aligned}
$$

Ayat di atas menjelaskan bahwa hakam yang diutus yaitu dari kalangan keluarga baik dari pihak suami maupun pihak istri. Imam Syihabuddin Mahmud al-Alusi, mengatakan bahwa pihak ketiga boleh dari luar keluarga kedua belah pihak dengan pertimbangan jika pihak ketika tersebut lebih maslahat dan membawa kerukunan rumah tangga yang sedang berselisih. (Abbas, 2009: 189)

Hubungan keluarga bukan syarat mutlak akan sahnya seorang hakam dalam menyelesaikan syiqaq. Namun, pihak ketiga dari kalangan keluarga dipertimbangan lebih mengetahui selukbeluk rumah tangga serta pribadi masingmasing pihak suami istri dan ia benar orang yang menginginkan tercapainya perdamaian dan kebahagiaan keduanya, sehingga mediasi yang akan berlangsung diharapkan sesuai dengan pokok tujuan mengembalikan ikatan perkawinan yang telah retak.

Perceraian yang dilalui melewati proses mediasi tentu mempunyai perbedaan dengan perceraian yang tidak melalui tahap mediasi, begitu juga dengan perceraian pasangan TKI. Perceraian pasangan TKI yang melalui proses mediasi meskipun gagal sekalipun, diharapkan putusan Majelis Hakim yang dibacakan dapat diterima dengan legowo (lapang dada) oleh kedua belah pihak secara baik-baik. Sebab dalam mediasi sudah diputuskan pendapat masingmasing untuk tetap bercerai sesuai keinginan dan kesadaran para pihak.

\section{EFEKTIFITAS MEDIASI DALAM MENYELESAIKAN PERSELISIHAN KELUARGA TKI}

Intensitas konflik rumah tangga sangat mempengaruhi proses mediasi. Mediasi perceraian sesungguhnya dilakukan guna memberikan masukan dan pertimbangan yang positif kepada para pihak untuk melakukan pilihanpilihan terlebih dahulu terhadap keinginan bercerai. Sebab perceraian mempunyai akibat yang tidak hanya berdampak pada kedua belah pihak, namun bagi seluruh anggota keluarga terutama anak.

Memperhatikan hasil mediasi yang dilakukan oleh Pengadilan Agama Ponorogo, penulis mengambil ikhtisar halhal yang bisa mempengaruhi keberhasilan dalam memediasi, di antaranya; faktor peraturan yang terkait (PERMA No. 1 tahun 2016; faktor mediator yang menangani; faktor fasilitas yang digunakan; serta faktor iktikad baik dari kedua pihak yang bersengketa (Farhan Asyhadi, 2019: 46 ).

Faktor peraturan yang menjadi payung hukum mediasi, dalam hal ini adalah PERMA No 1 tahun 2016, adalah sejauh mana peraturan tersebut memberikan dasar mediasi yang bisa mencakup permasalahan keluarga yang semakin kompleks. Sejauh ini segala persoalan yang timbul terkait mediasi sudah tercover di dalam peratuuran tersebut termasu penggunaan alat komunikasi jika para pihak berjauhan. Hal ini dijelaskan dalam pasal 5 ayat (3):

"Pertemuan Mediasi dapat dilakukan melalui media komunikasi audio visual jarak jauh yang memungkinkan semua pihak saling melihat dan mendengar secara langsung serta berpartisipasi dalam pertemuan." 
Selajutnya faktor mediator, dalam hal ini mediasi yang dilkaukan oleh mediator yang memiliki skill dan pengalaman berpengaruh dalam keberhasilan menyelisihi sengketa para pihak. Kompetensi atau kemampuan mediator dalam hal ini adalah kualifikasi dan keahlian mediator, yang secara ideal harus sesuai dengan kebutuhan para pihak, yang mana latar belakang keilmuannya dapat dijadikan sebagai alat untuk membantu para pihak memecahkan permasalahan dan memberikan solusi atas permasalahan yang terjadi. Keahlian mediator ini juga bisa mencakup penggunaan kata dan Bahasa dalam memediasi kedua pihak. Keberhasilan mediasi bahkan juga bisa ditentukan oleh tuturan yang digunakan oleh hakim mediator (Muslim, 2019: 300). Hal ini sesuai dengan Pedoman Perilaku Mediasi Pasal 8.

Selain kemampuan dan keahilan mediator dalam mendamaikan, perlu juga diperhatikan bagaimana beban kerja hakim yang bertambah selain memutus dan mengadili perkara sebagai tugas pokok, bertambah dengan memediasi pihak yang berperkara. Hal ini menyebabkan menumpuknya beban pemeriksaan sehingga mediasi yang berlangsung terkesan terburu-buru (Robi Maulana, Sutisna, 2020: 277).

Selain itu faktor fasilitas atau sarana prasarana yang digunakan atau yang memadai dalam pelaksanaan mediasi juga memberikan pengaruh dalam tingkat keberhasilan mediasi. Sebagaimana kondisi perceraian bagi TKI, keberadaan salah satu pihak yang berbeda tempat memungkinkan penggunaan fasilitas yang berbeda dengan mediasi di mana para pihak dapat bertemu langsung.
Terakhir adalah faktor sejauh mana iktikad baik para pihak. Hal ini sesuai dengan Pasal 7 PERMA No. 1 Tahun 2016. Iktikad baik ini tergambarkan sejak awal para pihak mengikuti mekanisme dan Langkah-langkah mediasi. Salah satu iktikad tidak baik yan tercermin diawal adalah tidak hadir setelah dipanggil secara patut 2 (dua) kali berturut-turut dalam pertemuan Mediasi tanpa alasan sah.

Pengadilan Agama Ponorogo secara prinsip telah melaksanakan mediasi pada perceraian pasangan TKI secara maksimal. Namun demikian, dalam tataran implementasi mediasi pasangan TKI masih mengalami kegagalan dan belum ada kekhususan dalam aplikasinya.

Adapun hal-hal yang dapat mempengaruhi penerapan mediasi pasangan TKI di Pengadilan Agama Ponorogo:

1. Salah satu pihak tidak hadir secara principal karena berada di luar negeri dan tidak mengirimkan kuasa atau mengirimkan kuasa istimewa namun dengan tujuan tetap untuk bercerai;

2. Penyebab perceraian yang sudah tidak dapat ditangani dan sangat fundamental seperti faktor ekonomi;

3. Belum ada evalusi secara rutin terhadap hasil mediasi secara umum dan mediasi pasangan TKI khususnya.

Memperhatikan penyebab perceraian dua putusan di atas, yaitu termohon (istri) tidak menurut dan patuh kepada pemohon sebagai suami dan tergugat orangya sudah tidak peduli lagi kepada keluarganya. Dengan demikian intensitas konflik dalam rumah tangga perlu mendapat perhatian serius dari seorang mediator sehingga proses negosiasi bisa berjalan efektif sesuai 
langkah dan tujuan yang telah ditentukan. Di sinilah mediator dituntut tanggap akan segala kondisi para pihak yang berkonflik.

Berikut adalah langkah-langkah mediator yang dapat dilakukan dalam proses mediasi pasangan TKI sesuai tinjauan normatif dan yuridis :

1. Memaksimalkan kewenangan sebagaimana ketentuan PERMA No. 1 Tahun 2016 tentang Prosedur Mediasi di Pengadilan

Secara eksplisit pertimbangan munculnya PERMA adalah proses mediasi dapat memberi akses yang lebih besar kepada para pihak untuk menemukan penyelesaian yang memuaskan dan dapat memenuhi rasa keadilan. Selain itu juga demi mengatasi penumpukan perkara di pengadilan serta memaksimalkan fungsi pengadilan selain bersifat memutus (ajudikatif). Perkara yang tidak menempuh proses mediasi bisa berakibat putusan batal demi hukum, maka secara prosedural mediasi bersifat imperatif (memaksa).

Sifat imperatif ini seyogyanya juga diimplementasikan dalam tataran praktik. Sehingga bagi kalangan TKI yang notabene jarak dan tempat menjadi kendala utama, penerapan ketentuan PERMA tentang penggunaan alat komunikasi sudah diperlukan. Penggunaan alat komunikasi dalam mediasi bagi yang tidak dapat bertatap muka dalam satu majlis, diharapkan juga dapat mencapai penyelesaian konflik, minimal menghindari putusan verstek serta mendapatkan hasil yang memuaskan dan memenuhi rasa keadilan bagi para pihak sebagaimana penjelasan di atas.
2. Mengutamakan keadilan dalam mediasi

Ajaran Islam menempatkan keadilan dalam mendamaikan orang yang bersengketa sebagai pondasi utama. Keadilan yang penyusun maksud adalah, memberikan ruang dan kesempatan kepada masingmasing pihak untuk mengungkapkan/ mengutarakan isi hati dan perasaannya atas konflik yang terjadi. Sebab, mediator dituntut mampu memetakan permasalahan. Tentu pemetaan tersebut didapat setelah mendengar langsung pendapat dari masing-masing pihak, dan pada akhirnya mediator dapat mengambil konklusi.

Ketidakhadiran pihak yang berada di luar negeri tentunya bukan menjadi halangan dalam memediasi. Meskipun ketidakhadiran tersebut disebabkan para pihak yang sudah tidak berkomuniasi layaknya suami istri atau intensitas konflik yang berat, namun dalam mediasi sangat dibutuhkan pandangan para pihak dalam menjelaskan konflik yang mereka alami. Sehingga, pada tahap akhir hasil mediasi bisa dikatakan sebagai hasil kesepakatan para pihak dan masing-masing pihak merasa lega.

3. Memediasi dengan mengajak para pihak yang berkonflik kembali kepada ajaran Allah SWT.

Firman Allah SWT. selanjutnya menerangkan :

$$
\text { وإن خفتم شقاق بينهما فابعثو اللهما حكما من أهله و أهلها إن يريدا إصلا حا يوفق الله بينهما إن }
$$

Ayat di atas dalam tafsir Jalalain Juz 1 surat an-Nisā' ayat 35 dijelaskan bahwa : kedua mereka (hakam) akan berusaha 
sungguh-sungguh dan menyuruh pihak yang aniaya supaya sadar dan kembali (al Mahalli \& al Suyuthi, 1990: 346).

Suami istri yang sedang berkonflik pada dasarnya karena mereka telah keluar dari ketentuan agama yang secara syar'i dilarang, seperti tidak ada tanggungjawab, selingkuh, dan sebagainya. Sehingga (hakam) mediator dalam mendamaikan masing-masing pihak untuk mengingatkan dan mengajak kembali ke ajaran Allah SWT. dan kembali mengedepankan konsep sakinah mawaddah warahmah dalam rumah tangga.

Menurut Imam Abu Hanifah, yang dimaksud dengan hakam adalah wakil, yakni orang yang mewakili pihak yang berselisih. (Abdullah \& Saebani, 2013: 201) Syeikh Jalaluddin al-Mahally memberikan kriteria syarat-syarat seorang hakam, yaitu "hakam itu merdeka, (jujur) serta punya pengetahuan tentang tugas-tugas yang dibebankan kepadanya". Syarat yang perlu mendapat perhatian kita adalah syarat terakhir yakni punya pengetahuan tentang tugas-tugas hakam. Dari sini dapat difahami bahwa hakam itu diutamakan seseorang yang memenuhi syarat, baik dari segi pengetahuan dan kemampuan sebagai hakam (Al-Mahally, 1979: 307).

Berpegang terhadap ketentuan yang ada baik dalam ajaran Islam dan ketentuan yuridis, mediator dapat menjalankan mediasi secara baik. Mempertimbangkan hal di atas, pasangan TKI yang salah satunya berada di luar negeri memerlukan penanganan tersendiri dan berbeda dalam menghadapi perselishian rumah tangga, sehingga mediator wajib memahami kondisi tersebut. Pada akhirnya jika semua elemen menjalankan tugas dan fungsi pokok (peran) masing-masing, terbukanya mediasi yang efektif.

Terakhir, penulis menyampaikan hipotesa bahan pertimbangan untuk mediasi bagi TKI atau kasus yang mirip jika salah satu pihak berada di luar jangkauan serta dapat dijadikan pertimbangan guna meningkatkan kualitas mediasi:

1. Kepada Pengadilan Agama Ponorogo, perlunya penggunaan media teknologi berupa internet seperti teleconference pada proses mediasi pasangan TKI yang salah satu pihak masih berada di luar negeri, sebagaimana ketentuan PERMA

2. Guna bahan mengantisipasi ketidakseimbangan antara hakim mediator dengan jumlah perkara, perlunya membuka pelatihan bagi sertifikasi mediator bagi non hakim.

3. Kepada Pengadilan Agama Ponorogo untuk mensosialisasikan mediasi kepada msyarakat umum guna menambah wawasan masyarakat tentang pentingnya mediasi dalam menyelesaikan konflik.

4. Adanya kerja sama semua pihak dalam hal ini perceraian pasangan TKI, sebab guna menekan angka perceraian pasangan TKI bukan hanya tugas dan fungsi mediator, namun semua kalangan juga mempunyai peran masing-masing.

5. Kepada pemerintah Ponorogo dan jajarannya untuk membuka peluang atau lowongan pekerjaan yang mampu memberdayakan masyakarat Ponorogo, sehingga bekerja di luar negeri bukanlah satu-satunya jalan untuk memperbaiki perekonomian keluarga.

6. Kepada masyarakat yang akan melangsungkan pernikahan, untuk 
mempersiapkan segala sesuatu dengan bekal ilmu keagamaan dan kehidupan rumah tangga. Sehingga mahligai pernikahan yang akan dibangun mempunyai pondasi dasar yang kuat untuk mengedepankan pernikahan yang sakinah mawaddah dan rahmah.

\section{KESIMPULAN}

Sesuai uraian yang penulis paparkan mengenai Mediasi Perceraian TKI di Pengadilan Agama Ponorogo di atas, maka dapat disimpulkan sebagai berikut:

1. Mediasi pada proses perceraian TKI di Pengadilan Agama Ponorogo dalam tataran implementasi berjalan sebagaimana mediasi pada perkara lain. Mediasi pada pasangan TKI di Pengadilan Agama Ponorogo tidak menggunakan metode atau cara khusus, seperti penggunaan alat komunikasi pada mediasi di mana para pihaknya tidak dapat bertatap muka sebagaimana ketentuan yang termuat dalam PERMA.

2. Selanjutnya mediasi pasangan TKI belum berjalan secara efektif, meskipun demikian Pengadilan Agama Ponorogo secara prinsip telah melaksanakan mediasi secara maksimal. Indikator ketidakefektifan di antaranya:

a. Upaya maksimalisasi amanat PERMA tentang penggunaan alat komunikasi belum terlaksana;

b. Keterbatasan hakim mediator dengan banyaknya jumlah perkara perceraian;

c. Kecilnya kemungkinan iktikad para pihak untuk rujuk akibat keruhnya konflik keluarga; d. Tingginya kegagalan perkara yang dimediasi di pengadilan agama dapat juga dihubungkan dengan para pihak yang tidak hadir dalam sidang pertama (Sururie, 2012: 15).

3. Secara prinsip, implementasi mediasi pasangan TKI di Pengadilan Agama Ponorogo telah sesuai dengan ketentuan hukum Islam dan hukum positif (normatif-yuridis). Namun demikian untuk mencapai hasil yang efektif dan maksimal, perlunya evaluasi secara rutin terhadap praktik mediasi bagi pasangan TKI di Pengadilan Agama Ponorogo. Selain itu juga mediator perlu menerapkan nilainilai agama dalam mendamaikan para pihak seperti, prinsip keadilan dan mengajak kembali ke jalan Allah SWT., sebagaimana firmannya dalam kitab suci Al-Qur'an.

\section{DAFTAR PUSTAKA}

Abbas, S. (2009). Mediasi dalam Perspektif Hukum Syariah. Hukum Adat, Dan Hukum Nasional. Jakarta: Kencana.

Abdullah, B., \& Saebani, B. A. (2013). Perkawinan dan Perceraian Keluarga Muslim. Bandung: Pustaka Setia.

AF, E. M. (1987). Islam membina keluarga dan hukum perkawinan di Indonesia. Kota Kembang.

Al-Asqalani, A. H. I. H. (2015). Bulughul Maram. t.t.t: Pustaka Al-Kautsar.

Al-Mahally, J. (1979). Qalyuby wa Umairah. Dar al-Ihya'e al-Kutub al-'Arabiyah, Mesir, t. th.

al Mahalli, I. J., \& al Suyuthi, I. J. (1990). Tafsir Jalalain Berikut Asbabun Nuzul Ayat. Terj. Mahyudin Syaf. Bandung: Sinar Baru.

Badan Nasional Penempatan dan 
Perlindungan Tenaga Kerja Indonesia, bnp2tki.go.id, http:// www.bnp2tki.go.id/read/90 86/Penempatan-TKI-2010-2013.html, akses 17 Nopember 2014.

Badan Peradilan Agama Mahkamah Agung Republik Indonesia, Informasi Perkara Online,

http://infoperkara.badilag.net/, akses 22 Oktober 2014.

Bakker, A. (1986). Metode-metode filsafat. Yogyakarta: Ghalia Indonesia.

Departemen Agama R.I. (1984). Al-Qur'an dan Terjemahannya, Jakarta: Proyek Pengadaan Kitab Suci Al-Qur'an.

Fadili, A. (2019). Upaya Perdamaian Proses Perceraian Agama sebagai Family Counseling. 12(1), 1-21.

Farhan Asyhadi. (2019). Efektivitas Mediasi dalam Perkara Perceraian Di Pengadilan Agama Karawang. Jurnal Justisi Hukum, 4(1).

Hadi, S. (1997). Metodologi Research I. Yogyakarta: Yayasan Penerbit Fak. Psikologi UGM, 198.

Handayani, F., \& Syafliwar. (2017). Implementasi Mediasi dalam Penyelesaian Perkara Perceraian di Pengadilan Agama. Jurnal AlHimayah, 1(2), 227-250.

Harahap, R. D. K. A. (2013). Kesetaraan Laki-laki dan Perempuan dalam Hukum Perkawinan Islam. Sawwa: Jurnal Studi Gender, 8(2), 361-386.

Muawwanah, R. (2019). Realitas Gugat Cerai TKW (Asia Timur) di Kabupaten Ponorogo: Sebuah Tinjauan Hukum Islam. Edugama: Jurnal Kependidikan Dan Sosial Keagamaan, 5(2), 154-182. https://doi.org/10.32923/edugama. v5i2.975

Muslim, K. (2019). Tindak tutur direktif hakim mediator perempuan dalam mediasi perceraian di Pengadilan Agama Kelas 1A Padang. Kata, 3, 299-308.

https://doi.org/10.22216/jk.v3i2.469 4

Mustofa, M. B. (2017). Peran hakim mediator dalam proses mediasi perkara perceraian berdasarkan Perma No. 1 tahun 2016 di pengadilan agama tulungagung kelas I A. IAIN Ponorogo.

Nasution, R. D. (2019). Upaya Pemerintah Dalam Penanggulangan Perceraian Di Kabupaten Ponorogo. Penelitian Kesejahteraan Sosial, 18(1), 1-11.

Robi Maulana, Sutisna, S. G. (2020). Optimalisasi Peran Mediator Dalam Memediasi Kasus Perceraian Di Pengadilan Agama Cibinong Bogor. Edutech Consultant Bandung Jurnal Aksara Publik. 4(9), 267-278.

Rosadi, A. (2018). Perkembangan Peradilan Islam di Indonesia. Remaja Rosdakarya.

Saragih, R., \& Simanjuntak, M. F. E. (2020). Efektivitas Mediasi sebagai Alternative Dispute Resolution Terhadap Perkara Perceraian di Pengadilan Agama Pematangsiantar. Journal of Education, Humaniora and Social Sciences (JEHSS), 3(2), 734-742. https://doi.org/10.34007/jehss.v3i2. 405

Statistik, B. P. (2016). Ponorogo Dalam Angka 2016. Ponorogo: BPS Kabupaten Ponorogo.

Subana, M. (2005). Dasar-Dasar Penelitian Ilmiah. Bandung: Pustaka Setia.

Sunarto, M. Z. (2019). Mediasi dalam Perspektif Maqashid Syariah: Studi tentang Perceraian di Pengadilan Agama. AT-TURAS: Jurnal Studi Keislaman, 6(1), 97-115. https://doi.org/10.33650/at- 


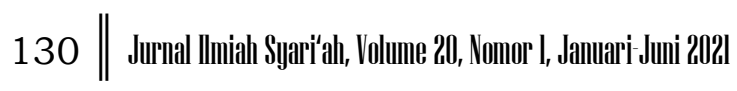

turas.v6i1.573

Sururie, R. W. (2012). Implementasi mediasi dalam sistem peradilan agama. Ijtihad: Jurnal Wacana Hukum Islam Dan Kemanusiaan, 12(2), 145. https://doi.org/10.18326/ijtihad.v12 i2.145-164.

Umar, H. M. (2020). Hukum Islam; Telaah Perkara Perceraian Melalui Proses Mediasi, 4(2), 175-186.

Usman, R. (2012). Mediasi di Pengadilan dalam Teori dan Praktik. Jakarta: Sinar Grafika.

Wirawan, K., \& Konflik, M. (2009). Teori Aplikasi dan Penelitian. Jakarta: Salemba Empat. 